\title{
Analisis Pengaruh Perencanaan Strategis SI/TI Dalam Meningkatkan Upaya Keunggulan Bersaing
}

\author{
Cindyasri Pratidina Setyanti ${ }^{1}$, Agustinus Fritz Wijaya ${ }^{2}$ \\ 1,2Fakultas Teknologi Informasi, Satya Wacana Christian University, Indonesia \\ E-mail:1682017092@student.uksw.edu, 2Agustinus.wijaya@uksw.edu
}

\begin{abstract}
SMKN 2 Salatiga really understands that the role of technology is very important, especially in terms of competition between SMA / SMK equivalents in the Central Java region. This study aims to develop IS / IT strategic planning in competing to increase school excellence, so that data collection is done through interviews, observation, and document study. The data will be taken regarding what factors can be strengths, weaknesses, opportunities, threats, and internal and external environmental analysis at SMKN 2 SALATIGA so that it can identify computer-based application designs that will support the progress of schools in Indonesia. implement a plan of excellence in competition between SMA / SMK and equivalent in Central Java
\end{abstract}

Keywords: Ward and Peppard, Five Forces Porter, SWOT

\section{PENDAHULUAN}

Persaingan antar sekolah yang terjadi sekarang ini semakin ketat di karenakan banyaknya sekolah yang juga mengikuti perkembangan teknologi[1]. Sebagai lembaga pendidikan yang menjadi penyedia jasa Pendidikan harus berusaha untuk memikirkan bagaiamana cara yang tepat untuk meningkatkan kepuasan pelanggan serta memenuhi kebutuhan para pelanggan yaitu para siswa dan wali murid dengan meningkatkan mutu pendidikan di sekolah[2]. Salah satu penilaian penting terhadap keberhasilan suatu sekolah adalah kemampuan dalam mempertahankan eksistensinya. Artinya sekolah tersebut perlu memiliki nilai keunggulan kompetitif dari pesaingnya. Keunggulan bersaing memberikan gambaran bagi perusahaan dalam memilih dan menerapkan strategi untuk meningkatkan serta mempertahankan daya saing.[3] 


\section{Journal of Software Engineering Ampera}

Vol. 1, No. 2, June 2020 e-ISSN: 2775-2488

https://journal-computing.org/index.php/journal-sea/index

Mutu pendidikan adalah gambaran dan karakteristik jasa pelayanan pendidikan secara internal ataupun ekternal yang menunjukkan kemampuannya dalam memuaskan kebutuhan yang diharapkan[4]. Dengan melihat Visi dan Msi yang ada pada SMKN 2 Salatiga dapat diketahui bahwa SMKN 2 Salatiga sangat mengikuti perkembangan teknologi yang ada trend saat ini, Peran sistem informasi tidak hanya untuk efisiensi dan efektifitas, namun juga sebagai strategi untuk menghadapi persaingan.

Sistem Informasi sekarang juga disebut sebagai senjata utama dalam strategi (strategic weapon) atau senjata kompetitif (competitive weapon), yaitu mampu digunakan sebagai alat ampuh untuk berkompetisi. Sistem informasi dalam pendidikan juga digunakan untuk mempertahankan posisi suatu sekolah dan meningkatkan keunggulan kompetitif[5]. Dapat disimpulkan bahwa keunggulan bersaing adalah kemampuan sekolah dalam menentukan strategi dan peluangpeluang yang menguntungkan perusahaan yang tidak mudah ditiru oleh pesaingnya dengan cara melakukan strategi inovasi dan peningkatan mutu.

Adapun tujuan dari penelitian ini yaitu (a) membuat perencanaan strategis sistem informasi untuk meningkatkan keunggulan kompetitif dalam bersaing, (b) membuat rekomendasi sistem informasi mendatang untuk SMKN 2 Salatiga. Untuk dapat menciptakan sumber daya manusia yang unggul dan kompetitif perlu ditunjang oleh pendidikan atau sekolah yang berkualitas.[6] Untuk menciptakan kualitas yang diinginkan tersebut maka SMKN 2 Salatiga dapat memberikan layanan yang maksimal kepada para peserta didik dengan memanfaatkan teknologi informasi.

\section{METODOLOGI PENELITIAN}

\subsection{Metode Penelitian}

Penelitian ini menggunakan metode deskriptif kualitatif yaitu dengan melakukan pengamatan, wawancara, dan studi dokumentasi. Penelitian ini terbagi ke dalam 4 tahap sebagai berikut:

1) Tahap pertama, melakukan identifikasi terhadap lingkungan organisasi melalui observasi, dan wawancara, dan pengumpulan data,

2) Tahap kedua, melakukan analisis terhadap lingkungan internal dan eksternal sekolah, serta dilakukan analisis porter's five forces model, Ward and Peppard, dan analisis value chain dengan cara mengidentifikasi sumber daya SI/TI yang tersedia saat ini, dan 


\section{Journal of Software Engineering Ampera}

Vol. 1, No. 2, June 2020 e-ISSN: 2775-2488

https://journal-computing.org/index.php/journal-sea/index

melakukan analisis terhadap lingkungan eksternal SI/TI dengan mengidentifikasi kebutuhan $\mathrm{SI} / \mathrm{TI}$ berdasarkan penggunaan $\mathrm{SI} / \mathrm{TI}$ relasi bisnis, dan perkembangan teknologi saat ini.

3) Tahap ketiga, membuat formulasi dengan menggunakan: analisis SWOT, dan analisis SI/TI sekolah

4) Tahap keempat, menyusun strategi bisnis sistem informasi, menyusun strategi manajemen sistem informasi dan teknologi informasi, dan menyusun usulan aplikasi yang akan datang. Secara menyeluruh kerangka konsep dalam penelitian ini digambarkan pada Gambar 1 dibawah ini :

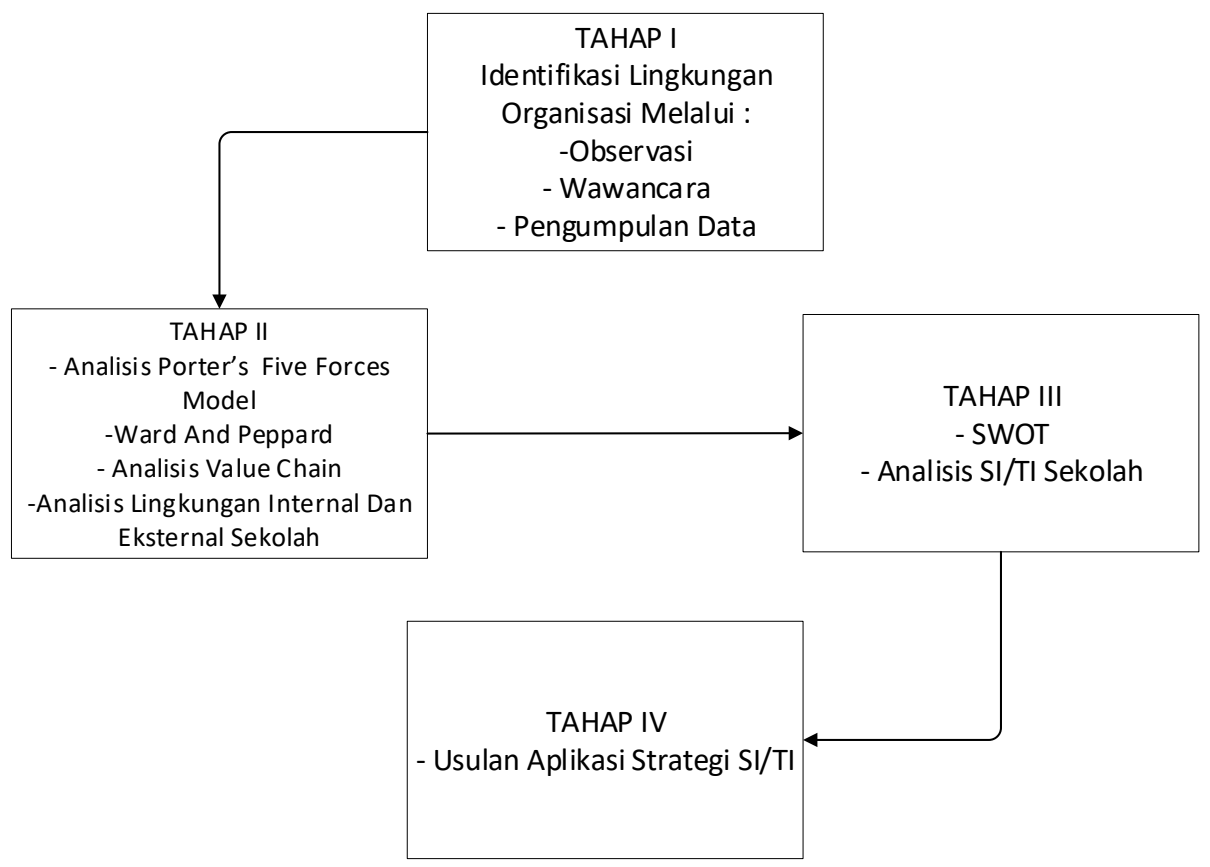

Gambar 1. Kerangka Penelitian Perencanaan Strategi SI/TI

\subsection{Analisis Porter's Five Forces Model}

Analisis Porter's Five Forces atau model lima faktor persaingan digunakan untuk menganalisa kondisi lingkungan eksternal yang sedang dihadapi oleh SMKN 2 Salatiga saat ini dengan menggunakan lima kekuatan bersaing yang akan menjelaskan posisi SMKN 2 Salatiga[7]. Jika dibandingkan dengan para pesaing sehingga mampu mengatasi tekanan-tekanan kompetisi di industri serta menciptakan keunggulan yang kompetitif.[8] Adapun penjelasan 
mengenai analisis lima faktor persaingan atau Porter's Five Forces terhadap SMKN 2 Salatiga yakni sebagai berikut:

1) Pesaingan Industri (Competitive Rivalry), Pesaing utama SMKN 2 Salatiga adalah SMK sederajat yang berada satu lokasi dengan SMKN 2 Salatiga. SMK sederajat yang sewilayah mempunyai potensi dalam mempengaruhi di bidang kegiatan belajar mengajar sekolah SMKN 2 Salatiga yang sudah menggunakan sistem informasi, maka SMKN 2 Salatiga tidak salah jika meraih julukan SMK Unggulan dikalangan SMK sederajat di lokasi tersebut.

2) Ancaman Pendatang Baru (Threat of New Entry), Ancaman pendatang baru SMKN 2 Salatiga adalah SMK Sederajat yang telah menerapkan SI/TI sehingga SMKN 2 Salatiga mempunyai daya saing di dunia industri, untuk mengatasi hal tersebut maka SMKN 2 Salatiga harus cepat dalam mengambil langkah agar dapat mengantisipasi hal tersebut.

3) Kekuatan Pembeli (Buyer Power), Masyarakat umum merupakan kekuatan pembeli bagi SMKN 2 Salatiga, dikarenakan orang tua (dalam konteks masyarakat umum) yamempunyai anak yang akan melanjutkan pendidikannya dari SMP ke jenjang yang lebih tinggi yakni SMK. Sekolah harus melakukan promosi dan sosialisasi terhadap orang tua yang mempunyai anak lulusan SMP sehingga orang tua dan anaknya mendaftarkan diri menjadi calon siswa di SMKN 2 Salatiga.

4) Kekuatan Pemasok (Supplier Power), Pemasok utama SMKN 2 Salatiga adalah SMP-SMP yang terdapat disekitar lokasi SMKN 2 Salatiga. SMK harus sering melakukan pendekatan dan sosialisasi terhadap siswa - siswi SMP yang disekitar lokasi SMKN 2 Salatiga, dikarenakan siswa siswi SMP tersebut bisa menjadi salah satu target penambahan calon siswa siswi SMK. Selain SMP di wilayah sekitar SMK, tenaga pendidik dan kependidikan merupakan kekuatan pemasok bagi SMKN 2 Salatiga. Dengan tenaga pendidik dan kependidikan yang handal dan berkualitas maka pelaksanaan ISO 9001:2008 di SMKN 2 Salatiga bisa dilaksanakan oleh pihak sekolah.

5) Ancaman produk pengganti (Threat of substitute products), Munculnya SMK dan lembaga pelatihan baru yang satu lokasi serta memiliki program keahlian yang sama dengan SMKN 2 Salatiga. Apalagi disertai dengan SMK dan lembaga pelatihan tersebut mempunyai link dan kerjasama (MOU) dengan pihak industri dan instansi pemerintahan maka SMK dan lembaga pelatihan tersebut akan menjadi ancaman/kompetitor yang luar biasa yang harus diwaspadai oleh SMKN 2 Salatiga 


\section{Journal of Software Engineering Ampera}

Vol. 1, No. 2, June 2020 e-ISSN: 2775-2488

https://journal-computing.org/index.php/journal-sea/index

Berdasarkan pemetaan diatas, maka kekuatan Lima Persaingan atau Porter's Five Forces yang ada di SMKN 2 Salatiga dapat dilihat melalui Gambar 2 dibawah ini.

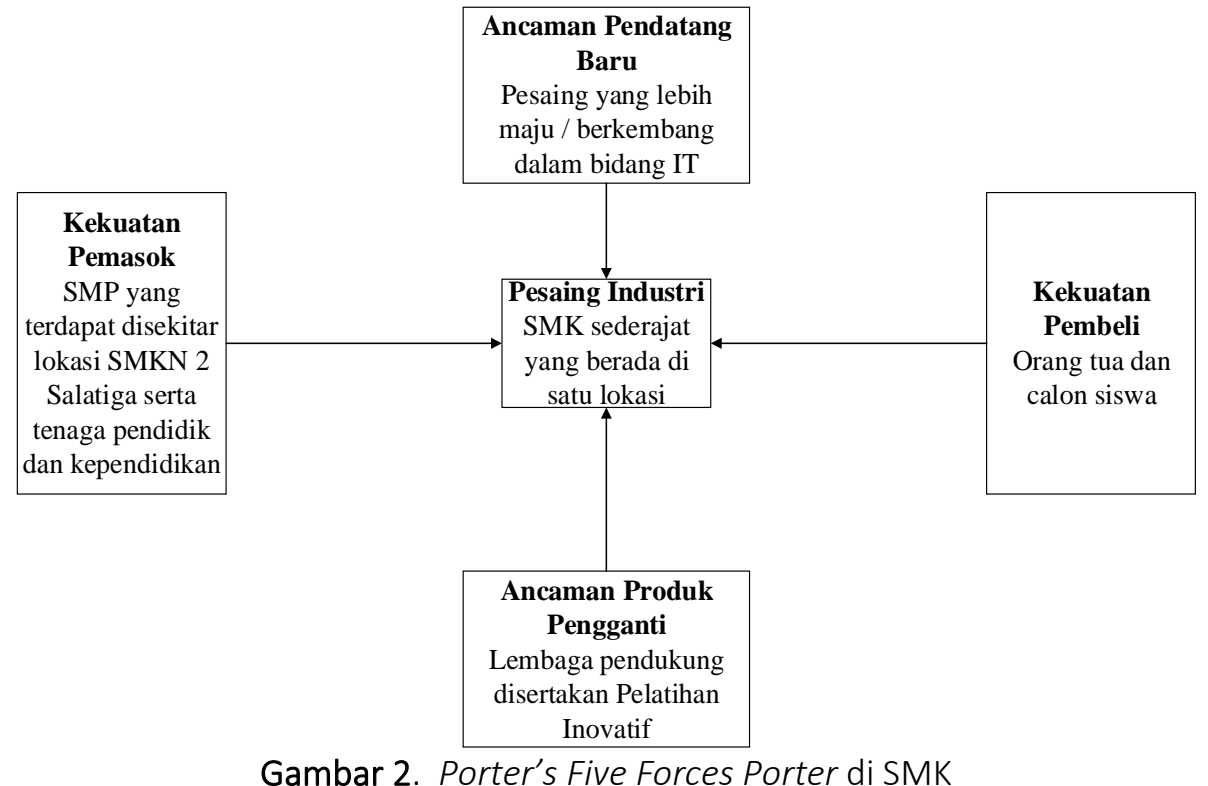

\subsection{Perencanaan Strategis SI/TI}

Analisis perencanaan strategis $\mathrm{SI} / \mathrm{TI}$ adalah analisis Ward and Peppard yang terdiri dari tiga bagian tahap utama yaitu masukan (input), keluaran (output), dan aplikasi (application). Tahapan masukan ini terdiri dari lingkungan internal, lingkungan eksternal, lingkungan SI/TI internal, dan lingkungan SI/TI eksternal. Tahapan keluaran terdiri dari strategis manajemen, strategis bisnis sistem informasi dan strategis teknologi informasi[9]. Tahapan aplikasi adalah hasil dari tahapan tersebut kemudian menghasilkan portofolio aplikasi yang dapat digunakan di masa yang akan datang. [10] Meneliti menggunakan metode Ward dan Peppard sesuai dengan perencanaan strategis SI/TI dalam meningkatkan upaya keunggulan bersaing, untuk mengidentifikasi kebutuhan $\mathrm{SI} / \mathrm{TI}$ dan memberikan strategi SI/TI yang sesuai dengan kondisi yang dihadapi . Meneliti kemampuan metode Ward dan Peppard untuk menghasilkan usulan usulan strategis $\mathrm{SI} / \mathrm{TI}$ yang mendukung pencapaian rencana strategis pada SMKN 2 Salatiga. Berikut gambar model perencanaan strategis SI/TI menurut Ward and Peppard: 


\section{Journal of Software Engineering Ampera}

Vol. 1, No. 2, June 2020 e-ISSN: 2775-2488

https://journal-computing.org/index.php/journal-sea/index

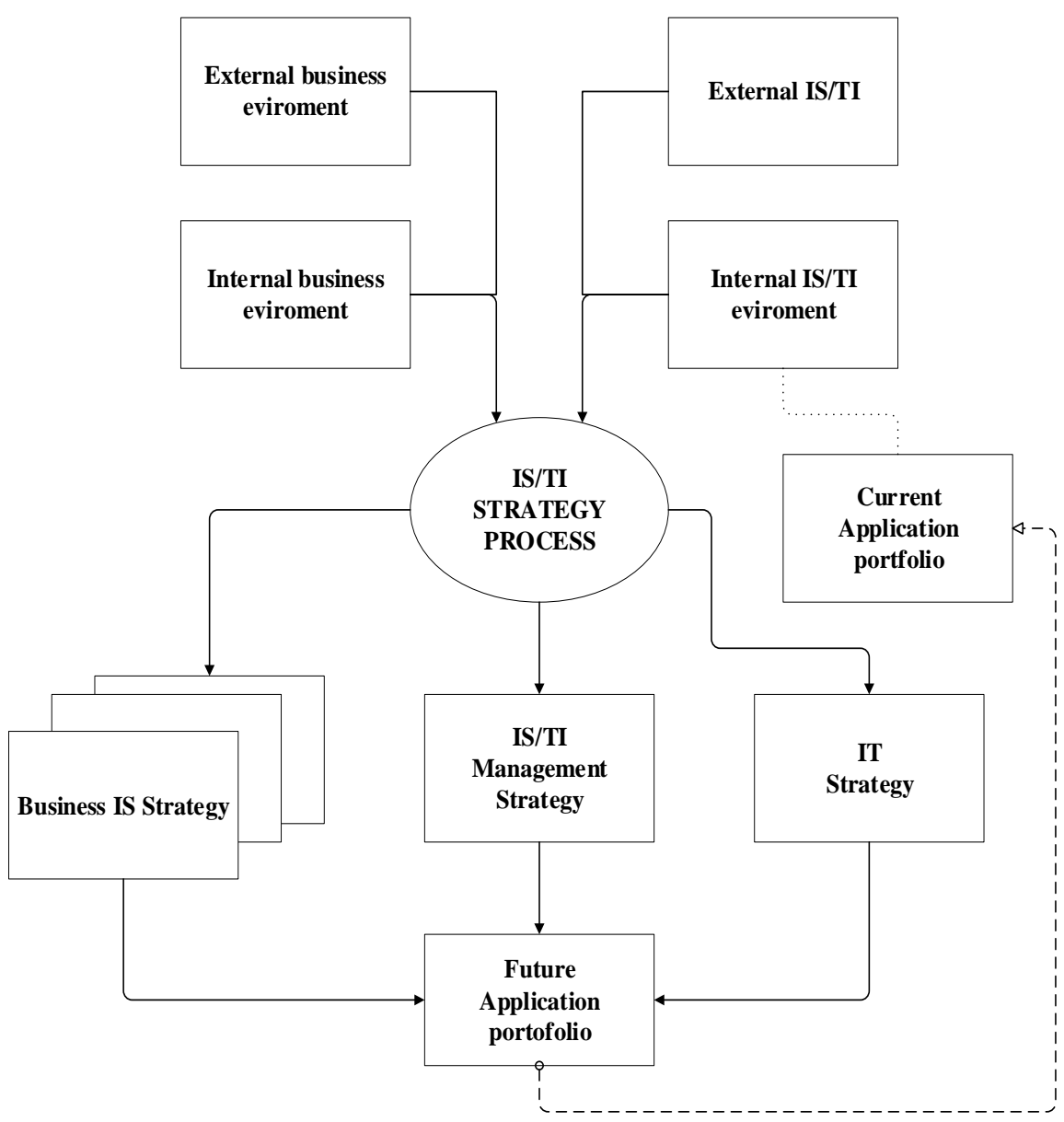

Gambar 3. Perencanaan Strategis SI/TI (Ward and Peppard 2002)

\subsection{Porter's Value Chain Analysis}

Tahap analisis yang selanjutnya adalah analisis lingkungan bisnis internal sekolah untuk mengetahui proses bisnis yang terjadi di SMKN 2 Salatiga sehingga dapat memperoleh gambaran yang jelas mengenai rencana strategis sistem informasi untuk memenuhi kebutuhan sekolah.[11] Analisis kedua yang digunakan yaitu Analisis Value Chain dilakukan untuk menggambarkan aktivitas proses bisnis utama dan proses bisnis pendukung dari SMKN 2 Salatiga, Analisis Value Chain juga bertujuan untuk mengidentifikasi dan mengelompokkan aktivitas - aktivitas yang terjadi di sekolah ke dalam dua bagian besar yaitu aktivitas utama dan aktivitas pendukung seperti pada Gambar 4 dibawah ini: 


\section{Journal of Software Engineering Ampera}

Vol. 1, No. 2, June 2020 e-ISSN: 2775-2488

https://journal-computing.org/index.php/journal-sea/index

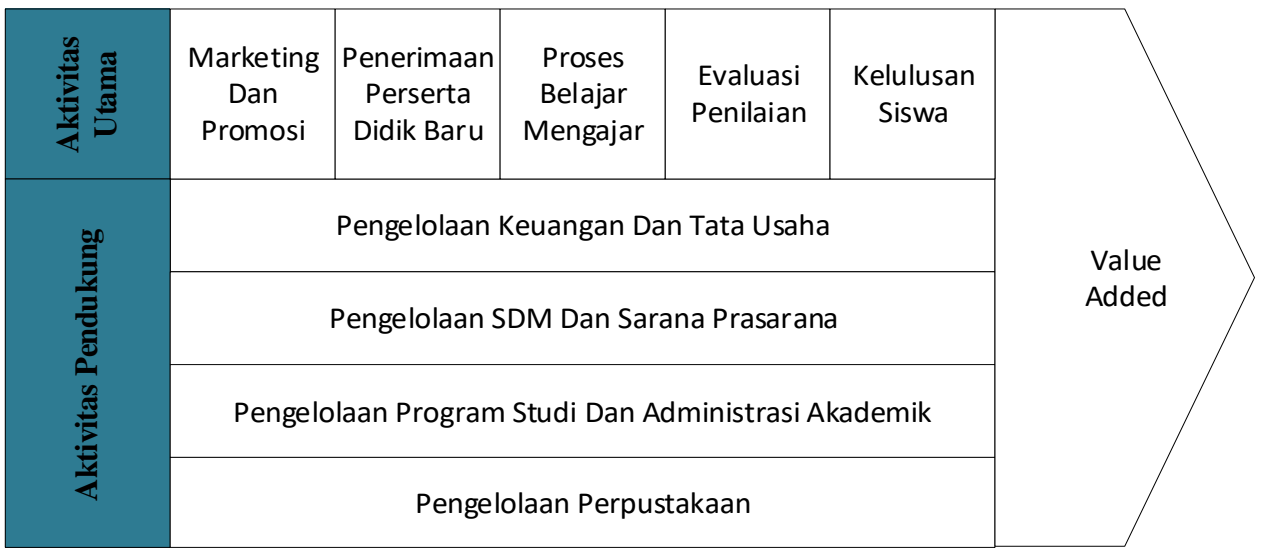

Gambar 4. Porter's Value Chain Analysis di SMKN 2 Salatiga

\subsection{Analisis SWOT}

Tahap analisis SWOT yaitu analisis untuk mengetahui kondisi bisnis dan SI/TI sekolah secara internal dan eksternal.

\section{1) Analisis Lingkungan Internal Sekolah}

Dalam analisis lingkungan internal didapatkan dari kekuatan (strengths) dan kelemahan (weakness) yang dimiliki oleh SMKN 2 Salatiga.

\section{- Kekuatan (Strengths)}

1. Sistem informasi yang dimiliki sekolah saling terintergrasi satu sama lain.

2. Memiliki finansial yang baik.

3. Memiliki jurusan yang berprofesi Teknik Komputer dan Jaringan yang mendukung untuk penerapan Sistem Informasi sesuai yang dibutuhkan oleh sekolah tersebut.

\section{- Kelemahan (Weakness)}

1. Kurangnya sumber daya manusia untuk mendukung aktivitas bisnis yang ada di sekolah.

2. Belum ada keamanan khusus pada aplikasi yang digunakan sekolah.

\section{2) Analisis Lingkungan Eksternal Sekolah}

Dalam analisis lingkungan eksternal sekolah didapatkan dari peluang (opportunities) dan ancaman (threat).

- Peluang (Opportunities)

1. Perkembangan teknologi informasi yang pesat dan modern serta ketersediaan aplikasi enterprise yang dapat langsung digunakan oleh sekolah. 


\section{Journal of Software Engineering Ampera}

Vol. 1, No. 2, June 2020 e-ISSN: 2775-2488

https://journal-computing.org/index.php/journal-sea/index

2. Lingkungan bisnis yang terus berkembang.

3. Peningkatan kualitas sekolah.

- Ancaman (Threats)

1. Berkurangnya sumber daya manusia sangat berpengaruh pada perkembangan proses bisnis teknologi pada sekolah.

\section{HASIL DAN PEMBAHASAN}

Berdasarkan hasil dari Analisa SWOT diatas dapat disimpulkan untuk menyusun perencanaan strategis sistem informasi manajemen di SMKN 2 Salatiga sebagai berikut:

1) Mengembangkan kekuatan dan memaksimalkan peluang (S-O)

a) Sekolah dapat memanfaatkan finansial yang ada untuk memperoleh sistem informasi yang dibutuhkan dengan cara membeli atau menyewa aplikasi yang tersedia di era masa kini sehingga sekolah dapat meningkatkan efektifitas dan efisiensi kinerja sekolah.

b) Sekolah dapat mengembangkan metode pembelajaran pada jurusan Teknik Komputer dan Jaringan yang mendukung untuk penerapan Sistem Informasi sesuai dengan kebutuhan sekolah sehingga dapat meningkatkan kualitas sekolah.

\section{2) Mengembangkan kekuatan dengan mengurangi ancaman (S-T)}

a) Sekolah dapat menggunakan finansial untuk membuat sistem informasi guna meningkatkan dan mengoptimalkan keunggulan sekolah dibidang teknologi informasi sehingga mampu bersaing kepada sekolah lainya yang sejenis.

b) Sekolah bisa meningkatkan kinerja sumber daya manusia serta sarana-prasarana untuk mendukung aktivitas bisnis sekolah. Sekolah juga meningkatkan metode pembelajaran khususnya pada jurusan Teknik Komputer dan Jaringan yang mendukung untuk penerapan Sistem Informasi sesuai yang dibutuhkan oleh sekolah.

\section{3) Meminimalkan kelemahan untuk memanfaatkan peluang (W-O)}

Sekolah harus lebih meningkatkan keamanan aplikasi yang ada saat ini dan meningkatkan sumber daya manusia agar pengelolaan lingkungan bisnisnya bisa berjalan dengan lancar sehingga kualitas sekolah semakin meningkat. 


\section{Journal of Software Engineering Ampera}

Vol. 1, No. 2, June 2020 e-ISSN: 2775-2488

https://journal-computing.org/index.php/journal-sea/index

4) Meminimalkan kelemahan dan menghindari ancaman (W-T)

a) Sekolah menggunakan sistem informasi modern yang berintegrasi data dengan baik yang dapat memberikan informasi secara lengkap dan detail seseuai kebutuhkan sehingga dapat bersaing dengan sekolah lainya.

b) Sekolah dapat mengembangkan sumber daya manusia serta sarana-prasarana dengan cara menambah dan mengevaluasi sehingga dalam lingkungan bisnis dapat terus berkembang serta kualitas sumber daya manusia dalam bidang pendidikan meningkat.

\section{5) Analisis Lingkungan SI/TI Sekolah}

Dalam melakukan identifikasi sistem informasi di SMKN 2 Salatiga, maka dilakukan analisis lingkungan $\mathrm{SI} / \mathrm{TI}$ secara internal menggunakan sistem informasi dan teknologi informasi yang tersedia[12]. Sistem informasi yang digunakan berbentuk dalam aplikasi ataupun perangkat keras, status aplikasi dan sumber daya manusia yang digunakan sebagai pengguna sistem informasi manajemen yang terdapat di SMKN 2 Salatiga[13]. Adapun daftar sistem informasi yang digunakan oleh SMKN 2 Salatiga saat ini seperti pada Tabel 1 di bawah ini:

Tabel 1. Daftar Sistem Informasi di SMKN 2 Salatiga

\begin{tabular}{|c|c|c|c|c|}
\hline $\begin{array}{l}\mathrm{N} \\
\mathrm{O}\end{array}$ & Nama SI & Pengguna & Status & Jenis \\
\hline 1 & SIKADU & Team IT, Tata Usaha, Guru, Dan Siswa. & $\begin{array}{c}\text { Terintegras } \\
\text { i }\end{array}$ & $\begin{array}{c}\text { Websit } \\
\text { e }\end{array}$ \\
\hline 2 & SIAHDU & $\begin{array}{l}\text { Team IT, Guru, Siswa, Dan Orang Tua } \\
\text { Siswa }\end{array}$ & $\begin{array}{c}\text { Terintegras } \\
\text { i }\end{array}$ & Mobile \\
\hline 3 & $\begin{array}{c}\text { E- } \\
\text { Perpustakaan }\end{array}$ & $\begin{array}{c}\text { Team IT, Guru, Siswa, Dan Masyarakat } \\
\text { Umum }\end{array}$ & $\begin{array}{c}\text { Terintegras } \\
\mathrm{i}\end{array}$ & Mobile \\
\hline
\end{tabular}

Berdasarkan hasil analisis yang diperoleh dari beberapa tahapan sebelumnya yaitu analisis lingkungan SI/TI SMKN 2 Salatiga baik lingkungan internal maupun eksternal, Berikut beberapa pengembangan aplikasi sistem informasi yang dapat diusulkan berdasarkan hasil analisis sebagai berikut:

1) SIPKER adalah aplikasi untuk pendaftaran penerimaan kerja di sekolah.

2) SIKES adalah aplikasi untuk mengelola kegiatan kesiswaan atau siswa.

3) SIPEM adalah menu untuk membagi link pembelajaran antar jurusan pada aplikasi siahdu 


\section{Journal of Software Engineering Ampera}

Vol. 1, No. 2, June 2020 e-ISSN: 2775-2488

https://journal-computing.org/index.php/journal-sea/index

Usulan strategi sistem informasi untuk SMKN 2 Salatiga, dapat disusun seperti pada Tabel 2 berikut.

Tabel 2. Daftar Usulan Sistem Informasi di SMKN 2 Salatiga

\begin{tabular}{ccccc}
\hline No & $\begin{array}{c}\text { Nama } \\
\text { SI }\end{array}$ & Pengguna & Status & Jenis \\
\hline 1 & SIPKER & $\begin{array}{c}\text { Kepala Sekolah, Calon Staf/Guru, } \\
\text { Tata Usaha, dan Team IT }\end{array}$ & $\begin{array}{c}\text { Baru dan Belum } \\
\text { diimplementasikan }\end{array}$ & Website \\
& & Guru, Siswa, Orang Tua Murid, \\
dan Team IT & $\begin{array}{c}\text { Baru dan Belum } \\
\text { diimplementasikan }\end{array}$ & Mobile \\
& SIKES & Team IT, Guru, Siswa, Dan Orang \\
Tua Siswa & Belum dimplementasikan & Mobile
\end{tabular}

\section{KESIMPULAN}

Penelitian ini menghasilkan rekomendasi, Berdasarkan Porter's Five Forces atau model lima faktor persaingan digunakan untuk menganalisa kondisi lingkungan eksternal yang dihadapi oleh SMKN 2 Salatiga saat ini. Analisa SWOT adalah identifikasi faktor secara sistematis untuk strategi sistem informasi sekolah dibagian lingkungan internal maupun lingkungan eksternal. Analisis ini dapat memaksimalkan kekuatan (Strengths) dan peluang (Opportunities), namun secara bersamaan dapat meminimalkan kelemahan (Weaknesses) dan ancaman (Threats). Hasil penelitian ini dapat digunakan oleh SMKN 2 Salatiga sebagai pertimbangan menentukan strategi SI yang tepat, sehingga dapat meningkatkan keunggulan kompetitif bersaing dengan sekolah lain.

\section{DAFTAR PUSTAKA}

[1] T. Kristanto, "Teknologi Informasi Pada PT Adira Dinamika Multi Finance," Semin. Nas. Sist. Inf. Indones., no. November, pp. 2-3, 2015.

[2] D. M. D. Kamayuda and M. A. Krismanda, "Perencanaan Strategi Bersaing Sekolah Dalam Meningkatkan Mutu Pendidikan Di Sekolah Swasta Salatiga," Satya Widya, vol. 32, no. 2, p. 79, 2016, doi: 10.24246/j.sw.2016.v32.i2.p79-91.

[3] S. Marina, "Pemasaran Kerelasian Dan Keunggulan Bersaing Unit Bisnis Kargo Pt Garuda Indonesia Relationship Marketing and Competitive Advantage in Business Cargo Unit Pt Garuda Indonesia," vol. 04, no. 03, 


\section{Journal of Software Engineering Ampera}

Vol. 1, No. 2, June 2020 e-ISSN: 2775-2488

https://journal-computing.org/index.php/journal-sea/index

pp. 267-276, 2017.

[4] I. S. Widiati, E. Utami, and H. Henderi, "Perencanaan Strategis Sistem Informasi Untuk Meningkatkan Keunggulan Kompetitif Sekolah Islam Terpadu," Creat. Inf. Technol. J., vol. 2, no. 4, pp. 329-340, 2015, [Online]. Available: https://citec.amikom.ac.id/main/index.php/citec/article/view/59.

[5] A. Zakiyudin AMIK BSI Karawang, "Membangun Kinerja Perusahaan Melalui Perencanaan Strategis Untuk Menciptakan Keunggulan Bersaing," vol. XVI, no. 1, 2018.

[6] E. Susena, E. Utami, and A. Sunyoto, "Perencanaan Strategis Sistem Informasi Smart Campus Untuk Meningkatkan Pelayanan di Politeknik Indonusa Surakarta," J. Sainstech Politek. Indonusa Surakarta, vol. 1, no. 3, pp. 1-17, 2015.

[7] Y. Utami, A. Nugroho, and A. F. Wijaya, "Perencanaan Strategis Sistem Informasi dan Teknologi Informasi pada Dinas Perindustrian dan Tenaga Kerja Kota Salatiga," J. Teknol. Inf. dan Ilmu Komput., vol. 5, no. 3, p. 253, 2018, doi: 10.25126/jtiik.201853655.

[8] D. wardhana Setya and A. R. Tanaamah, "Perencanaan Strategis Sistem Informasi Menggunakan Metode Ward And Peppard (Studi Kasus: Pada STMIK Parna Raya Manado)," Sent, vol. 16, no. 2, pp. 15-17, 2017.

[9] R. Berbasis, M. Ward, P. Studi, and K. Pt, "Kajian Perencanaan Strategis Sistem Informasi Pada Bisnis a Study of Strategic Planning Information System in Retail Bussiness Based on Ward \& Peppard Methodology: Case Study Pt . Gramedia Asri," vol. 6, no. 3, 2019, doi: 10.25126/jtiik.20196926.

[10] F. Risyda, "PERENCANAAN IT STRATEGIS PADA SMK AL-WAHYU JAKARTA DENGAN METODE WARD AND PEPPARD," no. 2, pp. 146-157, 2016.

[11] D. Indra and H. Sopryadi, "Perencanaan Strategis Sistem Dan Teknologi Informasi Pada St . Ignatius Education Center Palembang," Algoritma, vol. 4, no. 3, pp. 9-18, 2008.

[12] M. Agustina and S. O. Kunang, "Penerapan Knowledge Management System Pada Bidang Pelayanan Di SMA Satria Nusantara," vol. 1, no. 1, pp. 15-26, 2020.

[13] Y. Pratomo and R. A. Aziz, "Rencana Strategis Teknologi Informasi Menyongsong Transformasi Digital Di Dunia Pendidikan (Studi Kasus SMK Negeri 1 Sukadana Kabupaten Lampung Timur)," Jtksi, vol. 02, no. 03, pp. 74-81, 2019. 